\title{
The impact of hyperbaric oxygen therapy on the rate of wound healing in Fournier's gangrene
}

Wpływ tlenoterapii hiperbarycznej na szybkość gojenia ran w zgorzeli Fourniera

\author{
${ }^{1}$ Department of General, Functional and Oncological Urology, Military Institute of Medicine, Warsaw, Poland \\ ${ }^{2}$ Department of Urology and Urologic Oncology, Praski Hospital, Warsaw, Warsaw, Poland \\ ${ }^{3}$ Aesthetic Medicine for Doctors, Wojciech Korfanty Upper Silesian School of Economics, Katowice, Poland \\ ${ }^{4}$ Department of General, Oncological, Metabolic and Thoracic Surgery, Military Institute of Medicine, Warsaw, Poland \\ Correspondence: Agnieszka Grabińska, Department of General, Functional and Oncological Urology, Military Institute of Medicine, Szaserów 128, 04-141 Warsaw, Poland, e-mail: urodent@wp.pl
}

Abstract Aim: The aim of the study was to assess the impact of hyperbaric oxygen therapy on the rate of wound healing in Fournier's gangrene. Materials and methods: This was a retrospective analysis of 13 patients treated for Fournier's gangrene at the Military Institute of Medicine from October 2017 to November 2020. The study group consisted of males ( $n=13$ ) aged 24 to 83 years. Two groups of patients were distinguished: group 1 - patients who underwent hyperbaric oxygen therapy as an adjuvant treatment, group 2 - patients who did not undergo hyperbaric oxygen therapy. Results: In the first group, hyperbaric oxygen therapy was used as an adjuvant treatment of wound healing in in 8/13 patients (62\%) with Fournier's gangrene. In this group, significant acceleration of this process and shorter hospital stay were observed (mean $=29$ days). In the second group, the hospitalisation time was significantly longer (mean $=51$ days) in 5 out of 13 patients $(38 \%)$. There were no deaths in either group 1 or group 2. Conclusions: Hyperbaric oxygen therapy is an effective adjuvant therapy in the treatment of Fournier's gangrene. It has an impact on the rate of wound healing and shorter hospitalisation time.

Keywords: Fournier's gangrene, hyperbaric oxygen therapy, treatment

Streszczenie Cel: Celem badania było określenie wpływu tlenoterapii hiperbarycznej na proces gojenia ran w zgorzeli Fourniera. Materiał i metoda: Badania przeprowadzono, poddając analizie retrospektywnej przypadki 13 chorych, których leczono z powodu zgorzeli Fourniera w Wojskowym Instytucie Medycznym w okresie od października 2017 do listopada 2020 roku. Badaną grupę stanowiły wyłącznie osoby płci męskiej $(n=13)$ w wieku $24-83$ lat. Wyodrębniono 2 podgrupy: grupa $1-8$ pacjentów, u których zastosowano tlenoterapię hiperbaryczną jako leczenie wspomagające, grupa 2 - 5 pacjentów, u których ta terapia nie została zastosowana. Wyniki: W grupie 1 (62\% grupy badanej) u 8 z 13 pacjentów zastosowano tlenoterapię hiperbaryczną jako leczenie wspomagające gojenie ran w zespole Fourniera. W grupie tej stwierdzono zdecydowane przyspieszenie tego procesu i skrócenie czasu trwania hospitalizacji (średnio $29 \mathrm{dni}$ ). W grupie 2 ( $38 \%$ grupy badanej) u 5 z 13 pacjentów czas trwania hospitalizacji był dłuższy i wynosił średnio 51 dni. Zarówno w grupie 1, jak i w grupie 2 nie odnotowano przypadków śmiertelnych. Wnioski: Uzyskane wyniki badań wykazują, że tlenoterapia hiperbaryczna wpływa korzystnie na szybkość gojenia ran w zgorzeli Fourniera, powoduje znaczne skrócenie czasu hospitalizacji chorych, a także zmniejszenie liczby wykonywanych procedur chirurgicznych.

Słowa kluczowe: zgorzel Fourniera, tlenoterapia hiperbaryczna, leczenie 


\section{INTRODUCTION}

$\mathrm{F}$ ournier's gangrene (FG) is an aggressive and often fatal multi-microbial form of necrotising fasciitis involving the soft tissues of the perineum, rectum and external genital organs. It was first described by Jean Alfred Fournier, who reported 5 cases of young men with FG. Fournier's gangrene can develop at any age and is ten times more common in men than in women ${ }^{(1)}$. It usually causes painful scrotal or perineal swelling accompanied by sepsis. Physical examination shows small areas of necrotic skin with erythema and swelling. At a more advanced stage of the disease, foul-smelling, purulent discharge appears (Fig. 1).

Fever, chills, tachycardia and malaise are common systemic symptoms of $\mathrm{FG}^{(2)}$. Risk factors for increased mortality include immunosuppression, diabetes mellitus, alcoholism, atherosclerosis, malnutrition, recent urethral or perineal surgery, human immunodeficiency virus (HIV) infection, liver disease, leukaemia and obesity ${ }^{(3)}$. About $40 \%$ of patients present with an insidious onset of the disease, which manifests with mild scrotal, perineal and anal pain. The symptom is often ignored and therefore causes treatment delays. Fournier's gangrene can be caused by trauma, an insect bite, or unsafe sexual practices ${ }^{(4)}$. Computed tomography (CT) or magnetic resonance imaging (MRI) can be helpful in assessing rectal, perineal and scrotal involvement ${ }^{(4)}$. The degree of internal necrosis is usually higher than indicated by external symptoms. Surgical debridement should be performed within 24 hours as delay in the procedure increases the risk of death (Fig. 2) ${ }^{(5)}$. Immediate initiation of empiric broad-spectrum antibiotic therapy is recommended. The suggested regimen usually includes vancomycin or linezolid and piperacillin with tazobactam, optionally carbapenems or ceftriaxone and metronidazole ${ }^{(6)}$.

Hyperbaric oxygen therapy (HBOT) is a method that is increasingly used in the treatment of severe infections of soft tissues, FG in particular. It involves patient exposure to increased ambient pressure while breathing 100\% oxygen. Under HBOT conditions, oxygen is transported to cells both by haemoglobin and in the plasma. Research data show that $1 \mathrm{~L}$ of blood serum provides $3 \mathrm{~mL}$ of physically dissolved oxygen. Breathing

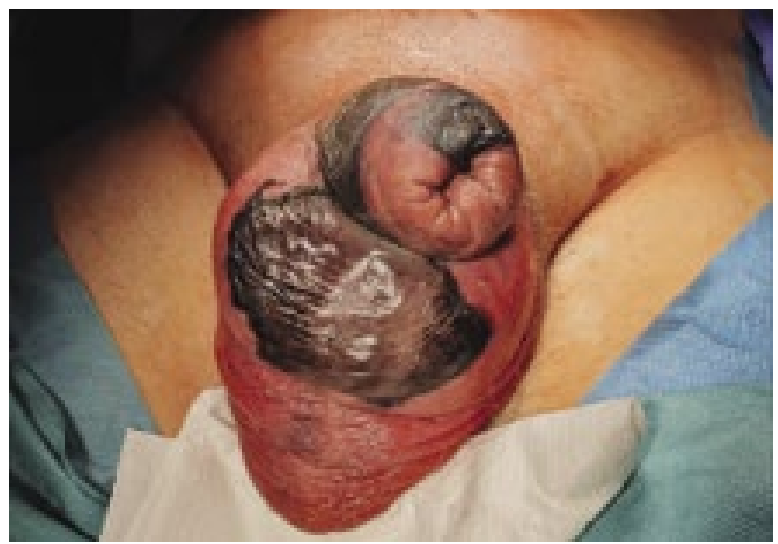

Fig. 1. Necrotic skin lesion of the penis and scrotum with subcutaneous tissue oedema with $100 \%$ oxygen under normobaric conditions ensures oxygen blood saturation at the level of $20 \mathrm{~mL} / \mathrm{L}^{(7)}$. The physiological effects of HBOT include increased ability of leukocytes to neutralise aerobic bacteria, stimulation of collagen formation and increased levels of superoxide dismutase, resulting in improved tissue vitality. Hyperbaric oxygen therapy is used as an adjuvant treatment, i.e. to support surgical interventions and broad-spectrum antibiotic therapy ${ }^{(5,8)}$.

Interdisciplinary treatment of FG involves a combination of surgical and urological interventions, antibiotic therapy, VAC dressing, HBOT and surgical reconstruction (Fig. 3).

\section{AIM OF THE STUDY}

The aim of the study was to assess the effects of hyperbaric oxygen therapy on the rate of wound healing in FG.

\section{MATERIALS AND METHODS}

This was a retrospective analysis of 13 patients treated for FG at the Military Institute of Medicine from October 2017 to November 2020. The study was approved by the Bioethics Committee of the Military Institute of Medicine. The study group consisted only of male subjects $(n=13)$ aged $24-83$ years (Tab. 1). Two groups of patients were distinguished: group 1 - patients who underwent HBOT as an adjuvant treatment, group 2 - patients who did not undergo HBOT. Hyperbaric oxygen therapy procedures were performed at the

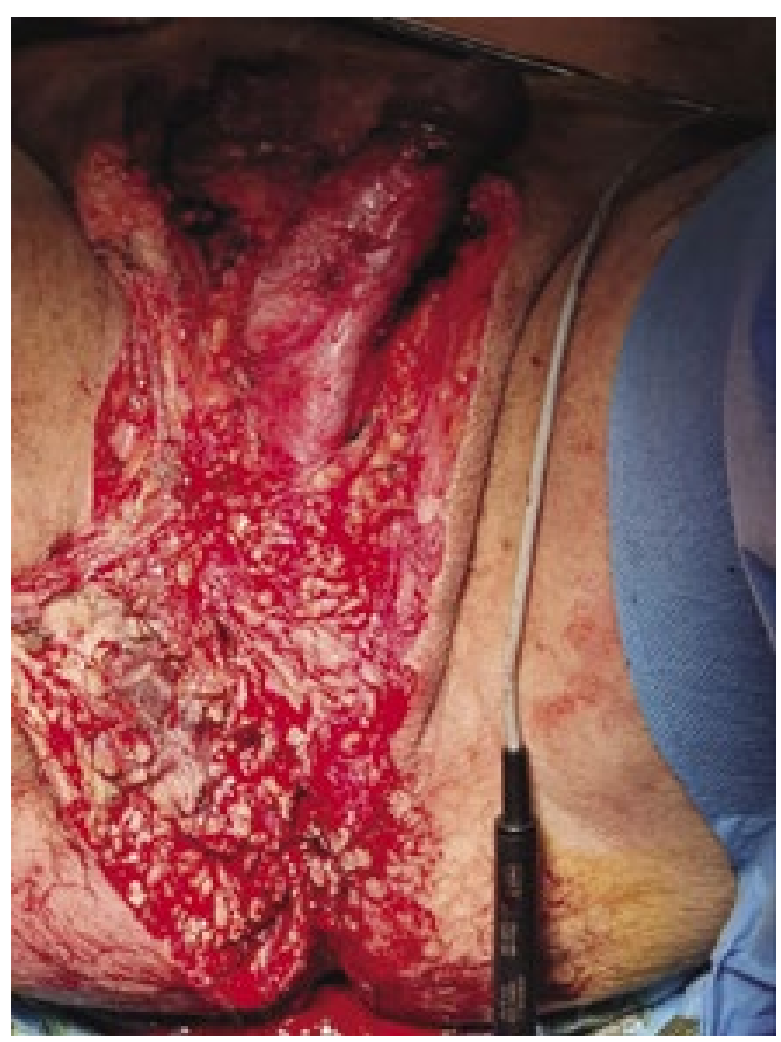

Fig. 2. Wide excision of the necrotic tissues of the lower abdomen, perineum, scrotum and buttock 


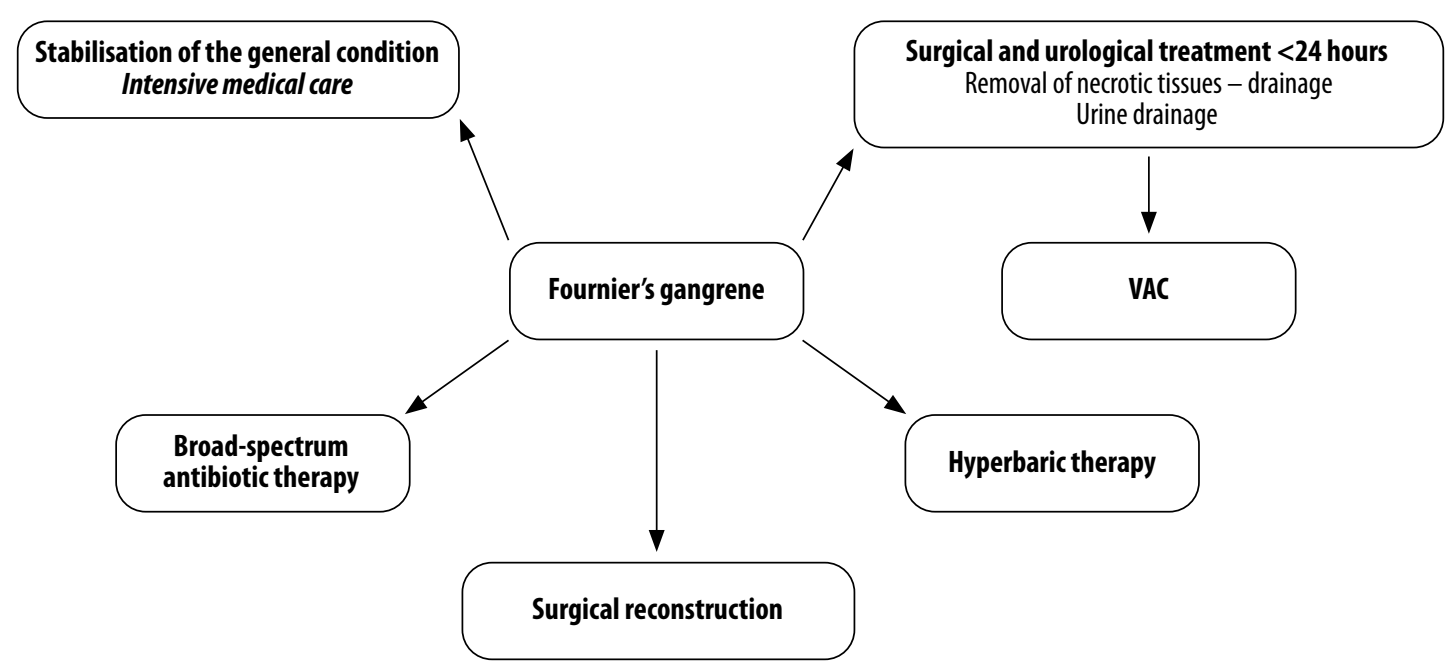

Fig. 3. Interdisciplinary treatment of $F G^{(9)}$ (modified by the authors)

Clinical Department of Hyperbaric Medicine of the Military Institute of Medicine in Warsaw. The standard treatment protocol uses pure oxygen in a hyperbaric chamber at 2.5 atmospheres absolute (ATA). Standard HBOT programme consists of 320 -minute sessions with 5-minute intervals when the patient breathes air. Additionally, the treatment includes 2 10-minute periods of compression and decompression at the beginning and at the end of the procedure, respectively. During these periods, patients also breathe air ${ }^{(10)}$.

Diagnosis of FG, i.e. necrotising soft tissue infection, and age $>18$ years were inclusion criteria. Failure to meet the inclusion criteria and contraindications to HBOT were the exclusion criteria. We assessed the following parameters: gender, age, comorbidities, laboratory tests on admission (C-reactive protein, CRP; white blood cells, WBC; haematocrit, HCT; platelets, PLT; sodium; potassium; creatinine; procalcitonin; international normalised ratio, INR), gangrene culture, antibiotic therapy used, length of hospital stay, number of surgical interventions and HBOT procedures.
Furthermore, comparative analyses of 2 groups of patients were performed to assess the impact of HBOT on the rate of wound healing in FG.

\section{RESULTS}

In group 1 , which consisted of 8 patients ( $62 \%$ of the study group), HBOT was used as an adjuvant treatment for FG wounds. In this group, the process of wound healing was significantly accelerated, and the length of hospital stay shorter (7-60 days, average 29 days). The mean age of patients in this group was 54 years. Laboratory findings were as follows: CRP 13.4-399.6 mg/dL (reference: 0-0.8 mg/dL; mean: $147.0 \mathrm{mg} / \mathrm{dL}$ ), WBC 4.56-29.2 × 109/L (mean: $14.0 \times 10^{9} / \mathrm{L}$ ), HCT $24.0-43.0 \%$ (mean: 36.0\%), PLT 170.0-405.0 × 109/L (mean: $283.2 \times 10^{9} / \mathrm{L}$ ), sodium 133.0-141.4 mmol/L (mean: $136.0 \mathrm{mmol} / \mathrm{L}$ ), potassium 3.1-5.5 mmol/L (mean: $4.0 \mathrm{mmol} / \mathrm{L}$ ), creatinine $0.4-4.75 \mathrm{mg} / \mathrm{dL}$ (mean: $2.0 \mathrm{mg} / \mathrm{dL}$ ), procalcitonin $0.88-340.6 \mathrm{ng} / \mathrm{mL}$ (mean: $109.0 \mathrm{ng} / \mathrm{mL}$ ), INR 1.06-1.77 (mean: 1.0).

\begin{tabular}{|c|c|c|c|c|c|c|c|c|c|c|c|}
\hline No. & НВОТ & $\begin{array}{c}\begin{array}{c}\text { Age } \\
\text { [years] }\end{array} \\
\end{array}$ & $\begin{array}{c}\text { CRP } \\
{[\mathrm{mg} / \mathrm{dL}]}\end{array}$ & $\begin{array}{c}\text { WBC } \\
{\left[\times 10^{9} / L\right]}\end{array}$ & $\begin{array}{l}\text { HCT } \\
{[\%]}\end{array}$ & $\begin{array}{c}\text { PLT } \\
{\left[\times 10^{9} / L\right]}\end{array}$ & $\begin{array}{c}\begin{array}{c}\text { Sodium } \\
{[\mathrm{mmol} / \mathrm{L}]}\end{array} \\
\end{array}$ & \begin{tabular}{|c|} 
Potassium \\
[mmol/L]
\end{tabular} & $\begin{array}{c}\text { Creatinine } \\
{[\mathrm{mg} / \mathrm{dL}]}\end{array}$ & $\begin{array}{c}\text { Procalcitonin } \\
{[\mathrm{ng} / \mathrm{mL}]}\end{array}$ & INR \\
\hline 1 & Yes & 50 & 399.6 & 28.2 & 36.8 & 170 & 139,2 & 3.87 & 1.33 & - & 1.06 \\
\hline 2 & Yes & 60 & 61.4 & 13.11 & 42.0 & 289 & 137 & 5.0 & 4.3 & 8.53 & 1.31 \\
\hline 3 & Yes & 24 & 46.6 & 7.11 & 43.0 & 280 & 133 & 3.9 & 1.9 & 85.92 & 1.35 \\
\hline 4 & Yes & 66 & 25.2 & 4.56 & 35.0 & - & 134 & 3.7 & 1.4 & - & - \\
\hline 5 & Yes & 69 & 166.4 & 13.69 & 36.7 & - & 141,4 & 3.1 & 1.0 & 0.88 & 1.36 \\
\hline 6 & Yes & 83 & 320.0 & 29.2 & 39.8 & 177 & 137 & 5.5 & 4.75 & 340.60 & 1.77 \\
\hline 7 & Yes & 43 & 13.4 & 8.76 & 24.0 & 378 & 134 & 4.6 & 0.8 & - & 1.26 \\
\hline 8 & Yes & 34 & - & 6.68 & 31.0 & 405 & 133 & 4.4 & 0.4 & - & 1.39 \\
\hline 9 & № & 73 & 38.1 & 20.50 & 34.0 & 119 & 138 & 4.7 & 1.6 & 21.10 & 1.54 \\
\hline 10 & No & 31 & 4.22 & 10.05 & 38.0 & 293 & 142 & 4.5 & 0.8 & - & 0.95 \\
\hline 11 & No & 42 & 0.1 & 10.12 & 38.0 & 244 & 143 & 4.7 & 1.3 & - & 1.01 \\
\hline 12 & № & 43 & 15.7 & 19.98 & 25.0 & 594 & 137 & 3.0 & 1.1 & 0.60 & 1.95 \\
\hline 13 & No & 55 & 23.1 & 16.65 & 35.0 & 378 & 116 & 7.3 & 1.2 & 1.16 & 1.12 \\
\hline
\end{tabular}

Tab. 1. Demographic and laboratory data of patients before treatment by division into group 1 (HBOT; blue) and group 2 (no HBOT; gray) 


\begin{tabular}{|c|c|c|c|c|}
\hline No. & HBOT [number of sessions] & Hospital stay [days] & Antibiotic therapy [days] & Number of surgical procedures \\
\hline 1 & 2 & 22 & 11 & 2 \\
\hline 2 & 2 & 46 & 22 & 3 \\
\hline 3 & 2 & 25 & 12 & 2 \\
\hline 4 & 6 & 7 & 15 & 2 \\
\hline 5 & 2 & 29 & 31 & 1 \\
\hline 6 & 2 & 60 & 17 & 1 \\
\hline 7 & 19 & 26 & 13 & 1 \\
\hline 8 & 3 & 22 & 22 & 2 \\
\hline 9 & 0 & 55 & 14 & 2 \\
\hline 10 & 0 & 23 & 7 & 2 \\
\hline 11 & 0 & 7 & 32 & 4 \\
\hline 12 & 0 & 64 & 33 & 3 \\
\hline 13 & 0 & 106 & & 6 \\
\hline
\end{tabular}

Tab. 2. An analysis of both groups for the length of hospital stay, antibiotic therapy and the number of surgical procedures

In group 2, which consisted of 5 patients (38\%), the hospital stay was longer and ranged from 7-106 days (mean 51 days). The mean age of patients in this group was 49 years. Laboratory findings were as follows: CRP $0.1-38.1 \mathrm{mg} / \mathrm{dL}$ (reference: $0-0.8 \mathrm{mg} / \mathrm{dL}$; mean: $16.0 \mathrm{mg} / \mathrm{dL}$ ), WBC $16.65-20.5 \times 10^{9} / \mathrm{L}$ (mean: $16.0 \times 10^{9} / \mathrm{L}$ ), HCT $25.0-38.0 \%$ (mean: 34.0\%), PLT 119.0-594.0 × 10\%/L (mean: 326.0 $\times 10^{9} / \mathrm{L}$ ), sodium $116.0-143.0 \mathrm{mmol} / \mathrm{L}$ (mean: $135.0 \mathrm{mmol} / \mathrm{L}$ ), potassium 3.0-7.3 mmol/L (mean: $5.0 \mathrm{mmol} / \mathrm{L}$ ), creatinine $0.8-1$, $6 \mathrm{mg} / \mathrm{dL}$ (mean: $1.2 \mathrm{mg} / \mathrm{dL}$ ), procalcitonin $0.6-21.1 \mathrm{ng} / \mathrm{mL}$ (mean: $7.62 \mathrm{ng} / \mathrm{mL}$ ), INR 0.95-1.95 (mean: 1.4) (Tab. 1).

The were no mortal cases in any of the groups.

Two patients ( 1 in each group) had diabetes mellitus. A history of cancer was reported in 4 patients ( 2 in each group). The following bacteria were obtained from gangrene cultures in group 1: Escherichia coli in 4, Pseudomonas aeruginosa in 2 and Enterococcus faecalis in 2 patients. Escherichia coli (1 patient), Enterococcus faecalis (1 patient), and Pseudomonas aeruginosa (3 patients) were detected in group 2 . The targeted antibiotic therapy primarily included metronidazole, vancomycin, clindamycin, carbapenems, piperacillin with tazobactam or linezolid. No correlation was found between the efficacy of HBOT, and the type of bacterial strain detected, or between the efficacy of HBOT and the type of antibiotic used. Between 1 and 6 surgical procedures (a mean of 2 procedures in group 1 and 3 procedures in group 2) were performed in the study group. The length of antibiotic therapy was 7-33 days (mean: 16 days in group 1 and 22 days in group 2). Furthermore, 2-19 HBOT sessions were performed in group 1 (a mean of 5 procedures) (Tab. 2).

\section{DISCUSSION}

Fournier's gangrene is a rare, severe disease. Despite advances in understanding its aetiology and pathophysiology, mortality rates in FG are still high, ranging from 3 and $45 \%^{(11)}$. If implemented early enough, HBOT contributes to effective treatment of severe diseases. Furthermore, imme- within 3-5 hours of symptom onset, is crucial ${ }^{(12)}$. Many conditions, such as diabetes, alcoholism, immunodeficiency, injuries and genitourinary infections, predispose to $\mathrm{FG}^{(12,13)}$. A 1980-2017 literature review covering prospective and retrospective randomised clinical trials showed a 5-10\% mortality in $\mathrm{FG}^{(14-16)}$. The higher risk of mortality correlates with advanced age, obesity and diabetes ${ }^{(17)}$.

In the study group, 2 patients ( 1 in each subgroup) had diabetes. A history of cancer was reported for 4 patients; however, no fatal cases were reported.

Lauerman et al. conducted a retrospective study on the duration of antibiotic therapy and the outcomes of FG treatment. The authors found no significant difference in mortality rates between patients who received parenteral antibiotics for $\leq 10$ days $(n=80)$ and those who received parenteral antibiotics $>10$ days $(n=88)^{(18)}$. A literature review on wound closure has shown that primary or secondary wound closure is recommended when the scrotal defect is $\leq 50 \%$, with advancement flap or skin graft needed for scrotal defects $>50 \%$ or extending beyond the scrotum ${ }^{(19)}$. In our study, the duration of antibiotic therapy was shorter in the HBOT group (mean of 16 days) than in non-HBOT group (mean of 22 days).

Li et al. demonstrated benefits of HBOT in 16 patients compared with 12 patients who did not receive this therapy, with reduced mortality and the need for fewer surgeries in the first group ${ }^{(19)}$. Anheuser et al. conducted a multicentre retrospective study in a group of 62 FG patients. HBOT was used in 17 patients and no fatalities were reported. HBOT was not used in 45 patients, and the mortality rate was $4.5 \%{ }^{(20)}$. This points to the benefits of using HBOT in patients with FG.

Creta et al. also showed that HBOT accelerates wound healing and improves survival rates in patients with FG. No deaths were reported in the HBOT group compared to $33.3 \%$ mortality in the non-HBOT group ${ }^{(21)}$.

In the current epidemiological situation caused by the outbreak of the COVID-19 pandemic, it is recommended that each hyperbaric medical facility reassess the risk associated 
with the use of HBOT in specific indications as an extension of the standard risk analysis and compliance with hospital recommendations. In severe cases of directly lifethreatening diseases, which are an indication for HBOT (e.g. gas embolism, necrotizing soft tissue infections, gas gangrene, severe carbon monoxide poisoning) in a patient with a confirmed diagnosis or suspicion of COVID-19, HBOT should be performed only after careful evaluation of all risks associated with the primary disease, comorbidities, transport options, as well as safe implementation of HBOT sessions ${ }^{(22)}$.

\section{CONCLUSIONS}

Hyperbaric oxygen therapy has a positive effect on the rate of wound healing in FG, as well as significantly reduces both the hospitalisation time and the number of surgical procedures performed.

\section{Conflict of interest}

The authors do not declare any financial or personal links to other persons or organisations that could adversely affect the content of this publication or claim rights thereto.

\section{Acknowledgements}

We wish to express our gratitude to all who contributed to this paper or made the patient data available. We also thank the employees of the Clinical Department of Hyperbaric Medicine of the Military Institute of Medicine in Warsaw.

\section{References}

1. Hung MC, Chou CL, Cheng LC et al.: The role of hyperbaric oxygen therapy in treating extensive Fournier's gangrene. Urol Sci 2016; 27: 148-153.

2. Singh A, Ahmed K, Aydin A et al.: Fournier's gangrene. A clinical review. Arch Ital Urol Androl 2016; 88: 157-164.

3. Schneidewind L, Anheuser P, Schönburg S et al.: Hyperbaric oxygenation in the treatment of Fournier's gangrene: a systematic review. Urol Int 2021; 105: 247-256.

4. Krishna Gowtham V, Vaishnavi A, Bhargav Narendra J: Case report on Fournier's gangrene. World J Curr Med Pharm Res 2020; 2: 191-193.

5. Chennamsetty A, Khourdaji I, Burks F et al.: Contemporary diagnosis and management of Fournier's gangrene. Ther Adv Urol 2015; 7: 203-215.

6. Stevens DL, Bisno AL, Chambers HF et al.; Infectious Diseases Society of America: Practice guidelines for the diagnosis and management of skin and soft tissue infections: 2014 update by the Infectious Diseases Society of America. Clin Infect Dis 2014; 59: 147-159.

7. Konturek S: Fizjologia człowieka. Podręcznik dla studentów medycyny. Elsevier Urban \& Partner, Wrocław 2007.

8. Wilkinson D, Doolette D: Hyperbaric oxygen treatment and survival from necrotizing soft tissue infection. Arch Surg 2004; 139: 1339-1345.

9. Drewa T, Juszczak K (eds.): Urologia. Ilustrowany podręcznik dla studentów i stażystów. PZWL, 2018.

10. Paprocki J, Gackowska M, Pawłowska $M$ et al.: Aktualne zastosowanie hiperbarii tlenowej. Med Rodz 2016; 19: 217-222.

11. Czymek R, Kujath P, Bruch HP et al.: Treatment, outcome and quality of life after Fournier's gangrene: a multicentre study. Colorectal Dis 2013; 15: 1529-1536.

12. Sieroń A, Cieślar G, Kawecki M (eds.): Zarys medycyny hiperbarycznej. a-medica press, Bielsko-Biała 2006.

13. Hong KS, Yi HJ, Lee RA et al.: Prognostic factors and treatment outcomes for patients with Fournier's gangrene: a retrospective study. Int Wound J 2017; 14: 1352-1358.

14. Furr J, Watts $\mathrm{T}$, Street $\mathrm{R}$ et al.: Contemporary trends in the inpatient management of Fournier's gangrene: predictors of length of stay and mortality based on population-based sample. Urology 2017; 102: 79-84.

15. Kim SY, Dupree JM, Le BV et al.: A contemporary analysis of Fournier gangrene using the National Surgical Quality Improvement Program. Urology 2015; 85: 1052-1057.

16. Sorensen MD, Krieger JN: Fournier's gangrene: epidemiology and outcomes in the general US population. Urol Int 2016; 97: 249-259.

17. Roghmann F, von Bodman C, Löppenberg B et al.: Is there a need for the Fournier's gangrene severity index? Comparison of scoring systems for outcome prediction in patients with Fournier's gangrene. BJU Int 2012; 110: 1359-1365.

18. Lauerman $\mathrm{MH}$, Kolesnik $\mathrm{O}$, Sethuraman $\mathrm{K}$ et al.: Less is more? Antibiotic duration and outcomes in Fournier's gangrene. J Trauma Acute Care Surg 2017; 83: 443-448.

19. Li C, Zhou X, Liu LF et al.: Hyperbaric oxygen therapy as an adjuvant therapy for comprehensive treatment of Fournier's gangrene. Urol Int 2015; 94: 453-458.

20. Anheuser P, Mühlstädt S, Kranz J et al.: Significance of hyperbaric oxygenation in the treatment of Fournier's gangrene: a comparative study. Urol Int 2018; 101: 467-471.

21. Creta M, Longo N, Arcaniolo D et al.: Hyperbaric oxygen therapy reduces mortality in patients with Fournier's gangrene. Results from a multi-institutional observational study. Minerva Urol Nefrol 2020; 72: 223-228.

22. Kot J, Marroni A, Welslau W; European Committee for Hyperbaric Medicine: ECHM position on Hyperbaric Oxygen Therapy (HBOT) in multiplace hyperbaric chambers during coronavirus disease (COVID-19) outbreak. 2020. Available from: https://www. uhms.org/images/Safety-Articles/ECHM-position-on-HBOTand-COVID-19-16th-March-2020_1.pdf [cited: 17 August 2021]. 